\title{
Clinical Study of Type 2 Diabetes Mellitus at Presentation and Assessment of Complications Associated with Type 2 Diabetes Mellitus
}

\author{
Dr praveen ${ }^{1}$, Dr Murugesh pastapur ${ }^{2}$, Dr Suresh Chincholi ${ }^{3}$ \\ ${ }^{1}$ Pg Department Of General Medicine Mrmc, Kalaburagi \\ ${ }^{2}$ Associate Professor, Department Of General Medicine, Mrmc, Kalaburagi, \\ ${ }^{3}$ Professor \& Hod, Department Of General Medicine, Mrmc, Kalaburagi,
}

\begin{abstract}
Background and objectives: Type 2 DM is the most prevalent form of diabetes mellitus seen in India. It constitutes more than $95 \%$ of diabetic population out of which $50 \%$ are undiagnosed and their mode of presentation varies considerably. Their glycemic status at diagnosis will be high and will have long standing hyperglycemia.
\end{abstract}

Objectives : To find out the various pattern of presentation, prevalence of obesity and family history, frequency and severity of complication, their glycemic status at diagnosis.

Methods: A total of 100 patients who were diagnosed as Type 2 DM on WHO criteria were included in this study. Patient with history of acute infection, pregnant women, on steroids, beta blockers and diuretics were excluded.

Results: Mean age of onset of DM was 48.38 \pm 10.72 years. Male: Female ratio 1.5:1. 29\% had family history of DM. Mean BMI was $24.87 \pm 5.34$. WHR 0.938 \pm 0.093 . Retinopathy was the most common presentation (29\%), followed by IHD (17\%) and neuropathy (16\%). The mean FBS, PPBS and HbAlc were 229.72 $\pm 92.12 \mathrm{mg} / \mathrm{dl}$ and $290.5 \pm 96.45 \mathrm{mg} / \mathrm{dl}, 9.31 \pm 1.63 \%$ respectively. TG, LDL and TC abnormalities were found in $25.5 \%, 45.7 \%$ and $17.02 \%$ of patients respectively.

Interpretation and conclusion: Diagnosis of Type 2 DM after the age of 35 years is very important as the incidence of complications increases as a duration of DM increases. Diabetes mellitus is often silent and must be controlled meticulously. The myth "cure for diabetes" which has rampantly spread among the diabetic population needs to be eradicated with the help of effective patient education programs. They commonly present with symptoms of hyperglycemia, and retinopathy. Complications increase with high values of FBS and HbAlc $\%$. Prevalence of macrovascular complications were low. The lipid abnormalities particularly with TG and LDL plays a major role in atherogenesis leading to microvascular complications and IHD. Early diagnosis with clinical presentation, examination and glycemic status helps to treat promptly and reduce mortality due to complications.

Keywords: FBS - fasting blood sugar, PPBS - post prandial blood sugar, IHD - Ischemic heart disease, HbAlc-Glycosylated hemoglobin

\section{Introduction}

Diabetes mellitus (DM), commonly referred to as diabetes, is a group of metabolic diseases in which there are high blood sugar levels over a prolonged period. Type $2 \mathrm{DM}$ is the most prevalent metabolic condition and one amongst major health and socioeconomic problems worldwide. It represents more than $90 \%$ of total prevalence of diabetes in the world ${ }^{1}$ and is responsible for $9 \%$ of the global mortality corresponding to four million deaths per year. Because early detection and prompt treatment may reduce the burden of diabetes and its complications screening for diabetes may be appropriate under certain circumstances. This position statement provides recommendation for diabetes screenings performed in physician's office and in other health care settings. ${ }^{2}$

Symptoms of high blood sugar include frequent urination, increased thirst, and increased hunger. If left untreated, diabetes can cause many complications. Acute complications can include diabetic ketoacidosis, nonketotic hyperosmolar coma, or death. Serious long-term complications include heart disease, stroke, chronic kidney failure, foot ulcers, and damage to the eyes. ${ }^{3}$

\section{Methodology}

The data will be collected from patients admitted to Basaveshwara Teaching \& General Hospital (BTGH), attached to H.K.E SOCIETY'S Mahadevappa Rampure Medical College, Kalaburagi, between December 2014 to August 2016 a total of 100 cases were included in the study. 


\section{Study was done on patients}

- Suspected of type $2 \mathrm{DM}$ on clinical presentation and referred to Basaveshwara Teaching \& General Hospital (BTGH) attached to H.K.E Society's Mahadevappa Rampure Medical College, Kalaburagi

- Admitted as inpatients for various other presentations and diagnosed as diabetes mellitus on routine screening for the first time.

\section{Inclusion criteria:}

- Both sexes

- $\quad$ Age (30-70) years

- Family history

- Patients previously told as DM but not on any treatment.

- Previous blood sugar level tests were in the normal range.

- Proved to have diabetes mellitus by FBS $>126 \mathrm{mg} / \mathrm{dl}$ or PPBS $>200 \mathrm{mg} / \mathrm{dl}$ on more than 2 occasions.

\section{Exclusion criteria:}

- Condition like acute infection, sepsis, burns.

- Endocrine disorders like acromegaly, thyrotoxicosis.

- Patients on steroids, beta blockers, diuretics.

- Acanthosis nigrans. Pregnant women

- Previous abnormal blood sugar level prior to 3 months.

Study started after taking informed consent from the patients. A detailed history was taken which included details regarding symptoms, mode of onset, complaints referable to different types of complications, diagnosis, and duration of diabetes a detailed clinical examination was done in all patients.

\section{Results}

In the present study, 100 patients of type 2 DM diagnosed for first time on WHO criteria were studied. Age and sex wise distribution was done clinical and laboratory profile were calculated with mean and standard deviation and the results are as follows:

Table -1: Age and sex wise distribution of cases

\begin{tabular}{|l|l|l|l|l|l|l|}
\hline \multirow{2}{*}{ Age } & Male & Female & \multicolumn{3}{l|}{ Total } \\
\cline { 2 - 7 } & No & $\%$ & No & $\%$ & No & $\%$ \\
\hline $30-35$ & 4 & 6.7 & 3 & 7.5 & 7 & 7.0 \\
\hline $36-40$ & 7 & 11.7 & 6 & 14.0 & 13 & 13.0 \\
\hline $41-45$ & 11 & 18.3 & 8 & 20.0 & 19 & 19.0 \\
\hline $46-50$ & 14 & 23.3 & 6 & 14.0 & 20 & 20.0 \\
\hline $51-55$ & 9 & 15.0 & 5 & 12.5 & 14 & 14.0 \\
\hline $56-60$ & 6 & 10.0 & 5 & 12.5 & 11 & 11.0 \\
\hline $61-65$ & 6 & 10.0 & 3 & 7.5 & 9 & 9.0 \\
\hline $66-70$ & 3 & 5.0 & 4 & 10.0 & 7 & 7.0 \\
\hline TOTAL & $60(60.0 \%)$ & 100.0 & $40(40.0 \%)$ & 100.0 & 100 & 100.0 \\
\hline $\begin{array}{l}\text { MEAN } \\
\text { SD }\end{array}$ & $48.54 \pm 11.61$ & $47.87 \pm 10.23$ & & $48.38 \pm 10.72$ \\
\hline
\end{tabular}

\section{Complications}

Table -2 Complications of Type 2 DM

\begin{tabular}{|l|l|l|}
\hline Complications & No.of cases & Percentage \\
\hline Retinopathy & 29 & 29.0 \\
\hline Nephropathy & 8 & 8.0 \\
\hline Neuropathy & 16 & 16.0 \\
\hline HTN & 9 & 9.0 \\
\hline IHD & 17 & 17.0 \\
\hline CVA & 8 & 8.0 \\
\hline PVD & 3 & 3.0 \\
\hline Infection respiratory pulmonary TB & 3 & 3.0 \\
\hline Others respiratory Infection & 3 & 3.0 \\
\hline Skin & 4 & 4.0 \\
\hline UTI & 2 & 2.0 \\
\hline Acute hyper glycemic complication & 7 & 7.0 \\
\hline
\end{tabular}


Clinical Study of Type 2 Diabetes Mellitus at Presentation and Assessment of ....

\begin{tabular}{|l|l|l|}
\hline DKA & 4 & 4.0 \\
\hline HHS & 3 & 3.0 \\
\hline Others & 5 & 5.0 \\
\hline
\end{tabular}

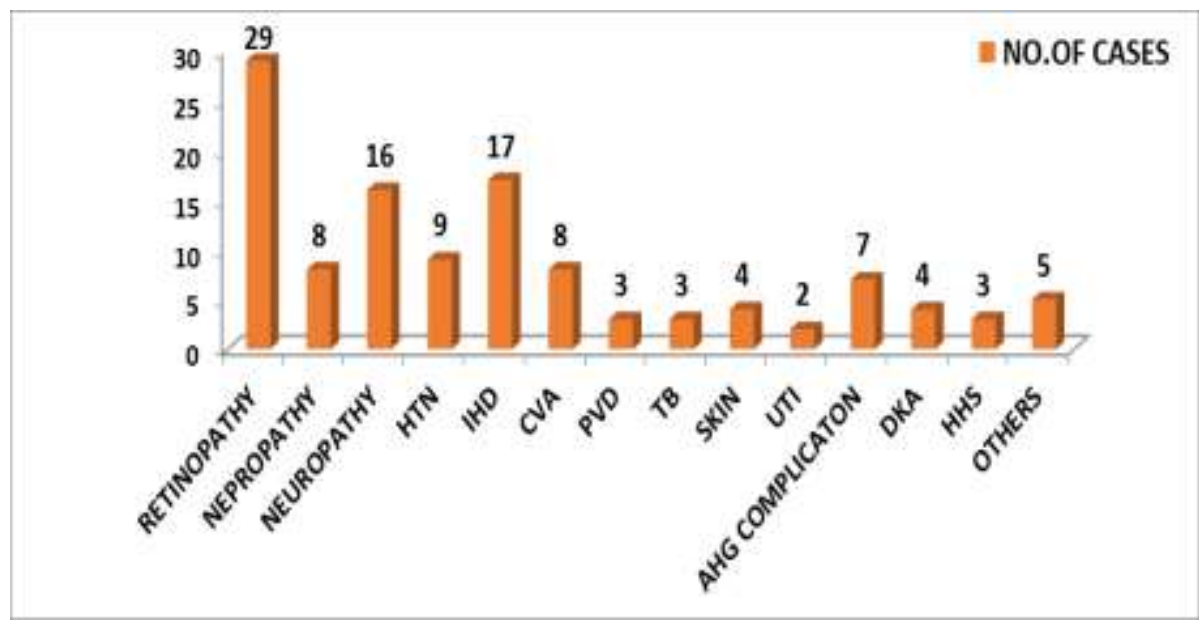

Graph: Complications of Type 2 DM

\section{Discussion}

Diabetes mellitus is a state of chronic hyperglycemia which is known to cause multiorgan dysfunction over a long period. Patients with type $2 \mathrm{DM}$ are commonly found to present late, often being diagnosed on routine examination or after the onset of a complication due to subtle symptoms of the disease ${ }^{4}$ This study was undertaken to determine the prevalence of complications of DM in a small section of society presenting to a tertiary Centre in south India to enable us to have a picture of the general pattern present in the society, which would help us determine the high risk groups and evolve screening strategies aimed at early diagnosis, thus reducing the morbidity due to the disease. In the present study a total of 100 patients diagnosed as type 2 DM on basis of WHO criteria were included.

Table 3: Comparing age of the patient with other studies

\begin{tabular}{|l|l|l|l|l|}
\hline & $\begin{array}{l}\text { Centers for Disease } \\
\text { Control and } \\
\text { Prevention } \\
\text { (CDC), }\end{array}$ & & & \\
Mean age \pm SD & $\begin{array}{l}\text { National Center for } \\
\text { years }\end{array}$ & Health & & \\
& Statistics, & Chennai study & & \\
& Rivision of & & & \\
& Realth & & & \\
& Interview & & & \\
& Statistics $2011^{5}$ & & & \\
\hline & $49.0 \pm 2.3$ & $52.97 \pm 9.7$ & $55.98 \pm 11.26$ & $48.38 \pm 10.72$ \\
\hline
\end{tabular}

Analysis of complications

\begin{tabular}{|c|c|c|c|c|c|c|c|}
\hline $\begin{array}{l}\text { Diabetic } \\
\text { Retinopathy }\end{array}$ & $\begin{array}{l}\text { Sankara } \\
\text { Nethralaya } \\
\text { Diabetic } \\
\text { Retinopathy } \\
\text { Epidemiology } \\
\text { and Molecular } \\
\text { Genetics } \\
\text { Study report } \\
2^{16}\end{array}$ & $\begin{array}{l}\text { Diabetic } \\
\text { retinopathy } \\
\text { among } \\
\text { self reported } \\
\text { diabetics in } \\
\text { southern India: } \\
\text { A } \\
\text { Population } \\
\text { based } \\
\text { Assessment }\end{array}$ & $\begin{array}{l}\text { Chennai } \\
\text { study }^{6}\end{array}$ & Rakesh $^{7}$ & $\begin{array}{l}\text { The } \\
\text { Chennai } \\
\text { Urban } \\
\text { Rural } \\
\text { Epidemiol } \\
\text { ogy study } \\
\text { (CURES) }^{8}\end{array}$ & $\begin{array}{l}\text { Ramachand } \\
\mathrm{Ra}^{9}\end{array}$ & $\begin{array}{l}\text { Present } \\
\text { study }\end{array}$ \\
\hline & $20.8 \%$ & $26.2 \%$ & $23.7 \%$ & $28 \%$ & $17.6 \%$ & $23.7 \%$ & $29 \%$ \\
\hline
\end{tabular}

Table 4: Comparing incidence of Diabetic retinopathy with other studies 
Clinical Study of Type 2 Diabetes Mellitus at Presentation and Assessment of ....

\begin{tabular}{|l|l|l|l|l|l|l|}
\hline \multirow{2}{*}{ Diabetic Nephropathy } & $\begin{array}{l}\text { Unnikrishnan } \\
\text { et al }^{10}\end{array}$ & $\begin{array}{l}\text { Chennai } \\
\text { study }^{6}\end{array}$ & Rakesh $^{7}$ & $\begin{array}{l}\text { Rochester } \\
\text { study }^{11}\end{array}$ & $\begin{array}{l}\text { Pirart } \\
\text { study }^{12}\end{array}$ & $\begin{array}{l}\text { Present } \\
\text { Study }^{2}\end{array}$ \\
\cline { 2 - 7 } & $2.2 \%$ & $5.55 \%$ & $4.7 \%$ & $2.7 \%$ & $8 \%$ & $8 \%$ \\
\hline
\end{tabular}

Table 5: Comparing incidence of Diabetic nephropathy with other studies

Table 6: Comparing incidence of Diabetic neuropathy with other studies

\begin{tabular}{|c|c|c|c|c|c|c|}
\hline \multirow{2}{*}{ Diabetic Neuropathy } & ${\text { Pradeepa et a } 1^{13}}^{13}$ & $\begin{array}{c}\text { Viswanathan } \\
\text { V et a }^{14}\end{array}$ & $\begin{array}{c}\text { Chennai } \\
\text { study }^{6}\end{array}$ & Rakesh $^{7}$ & Ramchandra et a1 $^{9}$ & Present study \\
\cline { 2 - 7 } & $26.1 \%$ & $14 \%$ & $27.5 \%$ & $43.7 \%$ & $27.5 \%$ & $16 \%$ \\
\hline
\end{tabular}

HTN: The incidence of hypertension in type 2 DM varies from $30-50 \%$ Ramchandra et al ${ }^{9}$ study on complications type $2 \mathrm{DM}$ has shown an incidence of hypertension in type $2 \mathrm{DM}$ as $36 \%$. In the present study the incidence is less $(9 \%)$

IHD: Gupta et a $1{ }^{15}$ study had $8.2 \%$ and Ramachandra et a $1^{9}$ study had an incidence of IHD in $11.5 \%$ of type 2 DM. In the present study the incidence is $17 \%$.

Table 7: Comparing incidence of CVA with other studies

\begin{tabular}{|l|l|l|l|}
\hline & ${\text { Ramchandra et } \mathrm{al}^{9}}$ & Chennai Study $^{6}$ & Present study \\
\hline CVA & $0.9 \%$ & $3 \%$ & $8 \%$ \\
\hline
\end{tabular}

Table 8: Comparing incidence of PVD with other studies

\begin{tabular}{|l|l|l|l|l|}
\hline & $\begin{array}{l}\text { Premalatha et } \\
\mathrm{al}^{18}\end{array}$ & Mohan et a1 & Chennai study $^{6}$ & Present study \\
\hline PVD & $6.3 \%$ & $3.9 \%$ & $4.5 \%$ & $3 \%$ \\
\hline
\end{tabular}

Infection: Skin Infection like dermatitis, folliculitis, cellulitis and UTI is $6 \%$ which is more than Chennai study and Ramachandra Pulmonary tuberculosis was present in 3\% of patients, as compared to $2.4 \%$ less in those without diabetes.

\section{Acute Hyperglycemic complications:}

The prevalence of DKA as presenting feature is about $10 \%$ of patients with undiagnosed diabetes as noted by V.Sheshaiah. In the present study it is $3 \%$ patients had HHS and $4 \%$ had DKA. So early diagnosis can reduce the incidence of this life threatening complications

\section{Conclusion}

The present study was an endeavor to estimate the prevalence of complications in new diabetics at diagnosis and to compare the changing trends, if any, at presentation. Males were more often affected than females. Family history was positive in $29 \%$ of the patients.

- $59 \%$ of the patients were less than or equal to 50 years of age. The blood sugar estimation may need to be done in younger age groups so as to effectively detect diabetes early.

- The percentage of asymptomatic patients i.e., those being incidentally detected was only $16 \%$.

- Nephropathy was found to be common with a proportion of patients in microalbuminuric phase, which is reversible if detected early.

- Incidental diabetes on evaluation during a hospital admission was much more common than those presenting for symptoms of hyperglycemia.

- There is a positive correlation between fasting blood sugar and serum glycosylated hemoglobin.

- As hyperglycemic status becomes chronic or long standing. (Increased blood sugar levels and $\mathrm{HbAlc}$ level) the complication particularly microvascular complication increases and significant number of patients had multiple complications $(>2)$ in $12 \%$ patients.

\section{Summary}

This cross sectional study entitled "Clinical study of type 2 diabetes mellitus at presentation and assessment of complications associated with type 2 diabetes mellitus" was conducted at Basaveshwara Teaching \& General Hospital (BTGH), attached to H.K.E Society's Mahadevappa Rampure Medical College, Kalaburagi, between period of December 2014-August 2016. 100 patients were studied on diagnosis of type 2 DM on WHO criteria. The study population had 60 males and 40 females. The mean age of onset of DM in present study was $48.38 \pm 10.72$ years.Family history of diabetes was present in $29 \%$ of patients. Most of patients (78\%) present 
with symptoms suggestive of complication of DM Retinopathy was the commonest presentation followed by ischemic heart disease, neuropathy.

Most of the patients also present on routine examination (16\%) and to other departments (5\%) followed by infections. The mean BMI in the present study is $24.87 \pm 5.34$ central obesity was present in $48 \%$ of patients, incidence of peripheral vascular disease, cerebrovascular disease were low. The patients in the study group had significant hyperglycemia with mean fasting and post prandial blood sugar were $229.72 \pm 92.12 \mathrm{mg} / \mathrm{dl}$ and 290.5 $\pm 96.45 \mathrm{mg} / \mathrm{dl}$ respectively. Glycosylated hemoglobin with mean HbA1C of $9.31 \pm 1.63 \%$. The fasting lipid profile: $45 \%$ had raised LDL and $25 \%$ had raised triglycerides. Present study results were compared with other studies of type 2 diabetes mellitus at presentation

\section{Bibliography}

[1]. Simon D. Epidemiological features of type 2 diabetes.Rev Prat 2010;60(4):469-7

[2]. ADA 2003 position statement. Diabetes care, column 26, supplement 1, January2003, page 21.

[3]. Shoback, edited by David G Gardner, Dolores (2011). Greenspan's basic \& clinical endocrinology (9th Ed.). New York: McGrawHill Medical. pp. Chapter 17. ISBN 0-0 7-1 62243-8.

[4]. Vijan 5, Stemens DZ, Herman WH, et al. Screening, prevention, counseling and treatment for complications of type II diabetes mellitus. Pitting incidence into practice. OrvHetil 1997 Aug 31; 138(35): 2175- 2178.

[5]. Centers for Disease Control and Prevention (CDC), National Center for Health Statistics, Division of Health Interview Statistics 2011, data from the National Health Interview Survey. Data computed by personnel in CDC's Division of Diabetes Translation, National Center for Chronic Disease Prevention and Health Promotion.

[6]. Mohan V, Ravikumar H. et al. Chennai Urban population survey Diabetolgia, 1997, 2000.

[7]. Rakesh et al. JAPI 2003 Dec; 51: 1166-1167.

[8]. Rema et al. IOVS, July 2005, Vol. 46, No.:7

[9]. Ramachandran A. Prevalence of vascular complications and their risk factors, in type 2 diabetes. JAPI 1999; 47(12): 1152-1156

[10]. Unnikrishnan RI, Rema M, Pradeepa R, Deepa M, Shanthirani CS, Deepa R, et a1.Prevalence and risk factors of diabetic nephropathy in an urban south Indian population: The Chennai Urban Rural Epidemiology Study (CURES - 45) Diabetes Care. 2007:30:2019-24

[11]. Krdewski AS and Warram JR. Epidemiology of late complications of diabetes. In: Joslin's diabetes mellitus. 13th Edn., Ed. Kahn CR and Weir GC, B.I. Waverly Pvt Ltd., New Delhi, 1996;11: 605-619.

[12]. Pirart J. Diabetes mellitus and its degenerative complications; a prospective study of 4400 patients observed. Diabetes Care 1978; $1: 168-88$

[13]. Pradeepa R, Rema M, Vignesh J, Deepa M, Deepa R, Mohan V. Prevalence and risk factors for diabetic neuropathy in an urban south Indian population: the Chennai Urban Rural Epidemiology Study (CURES-55) Diabet Med. 2008;25:407-12

[14]. Viswanathan V, Thomas N, Tandon N, Asirvatham A, Rajasekar S, Ramachandran A, et al. Profile of diabetic foot complications and its associated complications - a multicentric study from India. J Assoc Physicians India. 2005;53:933-6

[15]. Gupta R, Gupta VP, Sarna M, Bhatnagar 5, Thanvi J, Sharma V, et al. Prevalence of coronary heart disease and risk factors in an urban Indian population: Jaipur Heart Watch-2. Indian Heart J.2002; 54:59-66.

[16]. Raman R et al. Ophthalmology. 2009 Feb; 116 (2):311-8

[17]. V Narendran et al. BrJ Ophthalmol 2001; 86: 1014-1018

[18]. Premalatha G, Shanthirani S, Deepa R, Markovitz J, Mohan V. Prevalence and risk factors of peripheral vascular disease in a selected South Indian population. The Chennai Urban Population Study (CUPS) Diabetes Care. 2000;23:1295-300

[19]. . Mohan et al. High prevalence of MODY among Indians, Diabetes Care1985; 8: 371-379. 